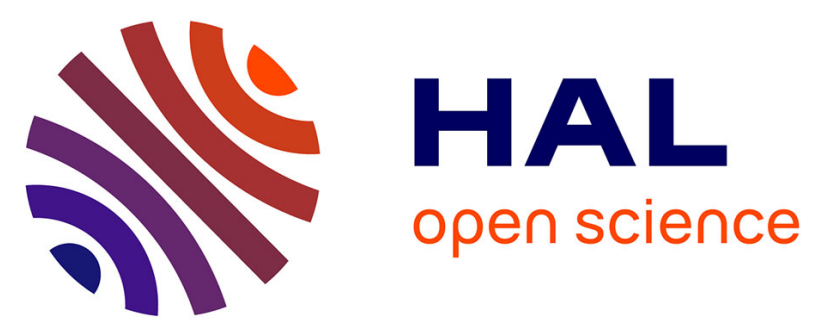

\title{
Ultrasound-Assisted Aromatisation with Condiments as an Enabling Technique for Olive Oil Flavouring and Shelf Life Enhancement
}

Karim Assami, Smain Chemat, Brahim Y. Meklati, Farid Chemat

\section{To cite this version:}

Karim Assami, Smain Chemat, Brahim Y. Meklati, Farid Chemat. Ultrasound-Assisted Aromatisation with Condiments as an Enabling Technique for Olive Oil Flavouring and Shelf Life Enhancement. Food Analytical Methods, 2016, 9 (4), pp.982-990. 10.1007/s12161-015-0273-9 . hal-01351180

\author{
HAL Id: hal-01351180 \\ https://hal.science/hal-01351180
}

Submitted on 27 May 2020

HAL is a multi-disciplinary open access archive for the deposit and dissemination of scientific research documents, whether they are published or not. The documents may come from teaching and research institutions in France or abroad, or from public or private research centers.

$$
\text { Copyright }
$$

L'archive ouverte pluridisciplinaire HAL, est destinée au dépôt et à la diffusion de documents scientifiques de niveau recherche, publiés ou non, émanant des établissements d'enseignement et de recherche français ou étrangers, des laboratoires publics ou privés. 


\title{
Ultrasound-Assisted Aromatisation with Condiments as an Enabling Technique for Olive Oil Flavouring and Shelf Life Enhancement
}

\author{
Karim Assami ${ }^{1,2} \cdot$ Smain Chemat $^{1} \cdot$ Brahim Y. Meklati $^{2} \cdot{\text { Farid } \text { Chemat }^{3}}^{3}$
}

\begin{abstract}
Olive oil flavour represents the most important factor that influences customer's perception for quality. In this study, an innovative aromatisation approach that enhanced quality and shelf life of olive oil is tested by means of in situ ultrasound-assisted extraction of Carum carvi L. seeds in olive oil. After the flavouring process, carvone and limonene, representing $99 \%$ of caraway essential oil, were identified in virgin olive oil as revealed by headspace solid-phase microextraction gas chromatograph coupled to mass spectrometer (HS-SPME gas chromatograph (GC)/mass spectrometer (MS)) analyses. Furthermore, kinetic studies indicate that flavouring rate in ultrasound-assisted system is faster than conventional aromatisation producing very stable aromatised oil with no changes in quality. This fact is attributed to ultrasound contribution to mass transfer intensification of essential oil components from seeds to the bulk medium, confirmed by scanning electron micrograph (SEM) micrographs in which cell damage and exudation of its main content are illustrated. However, it is important to note that ultrasound-treated samples produce higher degrees of conjugated dienes and conjugated trienes compared to conventional maceration. Nevertheless, this increase is not alarming and remains within
\end{abstract}

Karim Assami

assamikarim@hotmail.com

1 Centre de Recherche Scientifique et Technique en Analyses Physico-Chimiques (CRAPC), BP 248 Alger RP 16004, Algiers, Algeria

2 Laboratoire d'Analyse Organique Fonctionnelle, Faculté de Chimie, Université des Sciences et de la Technologie Houari Boumediene (USTHB), Bab Ezzouar 16111, Algiers, Algeria

3 Université d'Avignon et des Pays de Vaucluse, INRA, UMR408, Sécurité et Qualité des Produits d'Origine Végétale, 84000 Avignon, France permitted values of the European Community and the International Olive Oil Council (IOOC). Ultrasoundflavouring system stands as a fast alternative aromatisation method, which allows on top shelf life enhancement and olive oil quality preservation.

Keywords Ultrasound · Flavouring · Olive oil · Carum carviL. · Oxidative stability $\cdot$ Shelf life

\section{Introduction}

Olive oil represents, nowadays, a major source for fatty acids in Mediterranean diet regimen (Visioli and Galli 2002), mainly attributed to assertive nutritional and health benefits (Luaces et al. 2003). In Algeria, olive oil market has always played an important role in agriculture and food industry with an annual production of 45,000 t spread over 100,000 olive producers according to the International Olive Oil Council data (IOOC International Olive Oil Council 2009).

Generally, olive oil recovery from olive fruits (Olea europaea L.) is mainly performed via mechanical and physical methods such as hydraulic or cold pressing; then, a separation step from water by decanters is necessary before the filtration stage. In this situation, three different grades of olive oil suitable for consumption can be distinguished (extra virgin, virgin and ordinary) according to their acid value (or free acidity), expressed as grams of oleic acid equivalent per $100 \mathrm{~g}$ of oil. According to the International Olive Oil Council (IOOC) (IOOC International Olive Oil Council 2015), these grades have an acid value (AV) respectively of $<0.8 \%$ (extra virgin), $0.8 \%<\mathrm{AV}<2.0 \%$ (virgin) and $2.0 \%<\mathrm{AV}<3.3 \%$ (ordinary).

Olive oil consists of fatty acids (Ollivier et al. 2003), sterols (Jimnez de Bias and del Valle Gonzalez 1996), aroma 
Version définitive du manuscrit publiée dans / Final version of the manuscript published in :

Food Analytical Methods (2016), Vol. 9, issue 4, p. 982-990, DOI: 10.1007/s12161-015-0273-9

Journal homepage : www.springer.com/journal/12161

(Angerosa et al. 2004) and phenolics (Tripoli et al. 2005). Among these aroma compounds, distinctive sensorial properties can be attributed to the complex mixture of more than 100 volatile compounds (Morales et al. 1994). Commercial olive oils presenting off-flavours and a bitter taste are less attractive from a consumer perspective. However, this bitter taste attributed to glycosides is considered as a positive nutritional characteristic according to IOOC trade standard (IOOC International Olive Oil Council 2015).

Continuous efforts to meet client needs have been initiated by industries to look for specific olive oil products profiling an added value. Vegetable oil enriched with essential oil has made a significant breakthrough and was realised through direct topping (Damechki et al. 2001; Gambacorta et al. 2007). However, it is believed that the latter process induces an increase in oil acidity, thus altering its stability and calling for an extra refinery setup. Other methods such as infusion have been tested to aromatise oil with vegetables, fruits, herbs or flowers (Moldão-Martins et al. 2004). Traditionally, herbinfused olive oil is particularly used with crusty bread in Italy, whereas olive oil is infused in Spain with hot red peppers. Conventional flavouring of olive oil needs a simple setup but requires large storage tanks and long period of 4 to 6 weeks of maceration. In this respect, an ultrasound-assisted aromatisation method is proposed and compared to a conventional mixing, in an attempt to accelerate significantly the process without altering olive oil quality.

This technology offers several advantages over conventional techniques such as yield improvement and time reduction. For instance, Wei et al. (2008) reported a yield increase of more than $20 \%$ for rapeseed oil recovery using ultrasound over Soxhlet extraction technique. Furthermore, LuqueGarcia and Luque de Castro (2004) achieved great recovery of total fat from sunflower seeds with Soxhlet extraction assisted by ultrasound. Low solvent consumption associated with acceleration of heat and mass transfer as a result of positive cavitational effect is highly appreciated in the recovery of high-value compounds such essential oils, anthocyanins and beta-carotene from food waste (Galanakis 2012). Nonetheless, non-standardised methodologies and the absence of defined control parameters represent the main problems encountered during industrial process development (Galanakis 2013).

Largely used condiment, caraway fruits (Carum carvi L.) are selected for aromatisation of olive oil by means of conventional maceration versus ultrasound-assisted extraction. It belongs to the Umbelliferae family and characterised by a sweet and a slight peppery aroma fulfilled by its essential oil, mainly composed of antioxidant compounds such as carvone and limonene (Elmastas et al. 2006; Roberto et al. 2010). For this study, the comparison of olive oil aromatisation with caraway seeds is achieved by means of ultrasound and maceration. Olive oil quality is assessed through analyses of major compounds transferred from flaked carvi fruits into olive oil, free fatty acids yield, peroxide value, fatty acid composition and oxidation degree. Finally, the influence of aromatisation mechanism is studied by collecting scanning electron micrographs of caraway seeds' residue before and after processing.

\section{Materials and Methods}

\section{Materials}

Caraway seeds (C. carvi L.) and olive oil branded as virgin oil were purchased from a local supermarket (Algiers, Algeria). Reference compounds (S)-(+) carvone and (R)-(+) limonene of $98.0 \%$ purity were purchased from Sigma-Aldrich (Germany). All reagents were of analytical grades, and solvents of HPLC grades were supplied by Merck (Darmstadt, Germany).

\section{Isolation of Caraway Essential Oil by Hydrodistillation}

For comparison purposes, isolation and characterisation of C. carvi L. essential oil are performed in order to evaluate in terms of quality and quantity the transfer yield of major compounds from flaked seeds into olive oil. In this case, hydrodistillation procedure is used in which $150 \mathrm{~g}$ of caraway seeds was finely ground using an electric grinder (Ika, Germany) at 20,000 rpm over $20 \mathrm{~s}$. The flaked seeds were immediately submitted for hydrodistillation in a Clevengertype system (Clevenger 1928; ISO 1987) and extracted with $1.5 \mathrm{~L}$ of distilled water over $3 \mathrm{~h}$ (i.e. until no more essential oil was obtained). The essential oil was collected and analysed with gas chromatograph (GC)/mass spectrometer (MS) as described in earlier studies (Assami et al. 2012).

\section{Aromatisation Procedures}

In this section, two procedures were studied: conventional aromatisation and ultrasound-assisted aromatisation as explained on Fig. 1 that illustrates several stages involved in olive oil aromatisation by $C$. carvi $\mathrm{L}$.

\section{Conventional Aromatisation}

In the conventional system, $150 \mathrm{~g}$ of crushed caraway seeds was added to $1 \mathrm{~L}$ of virgin olive oil; this ratio has been selected according to literature, which recommends, for spices, the addition of 0.5 to $20 \%$ relative to olive oil weight (Van Boom et al. 2002). The mixture was placed into a 2-L double jacketed reactor into which cooling water circulates in order to keep the mixture at a constant temperature of $25^{\circ} \mathrm{C}$. The mixture was homogenised using a rotating pale at a speed of $1000 \mathrm{rpm}$ and left for several hours, with intermediate 
Fig. 1 Stages of olive oil aromatisation by Carum carvi L. using conventional maceration or ultrasound-assisted maceration

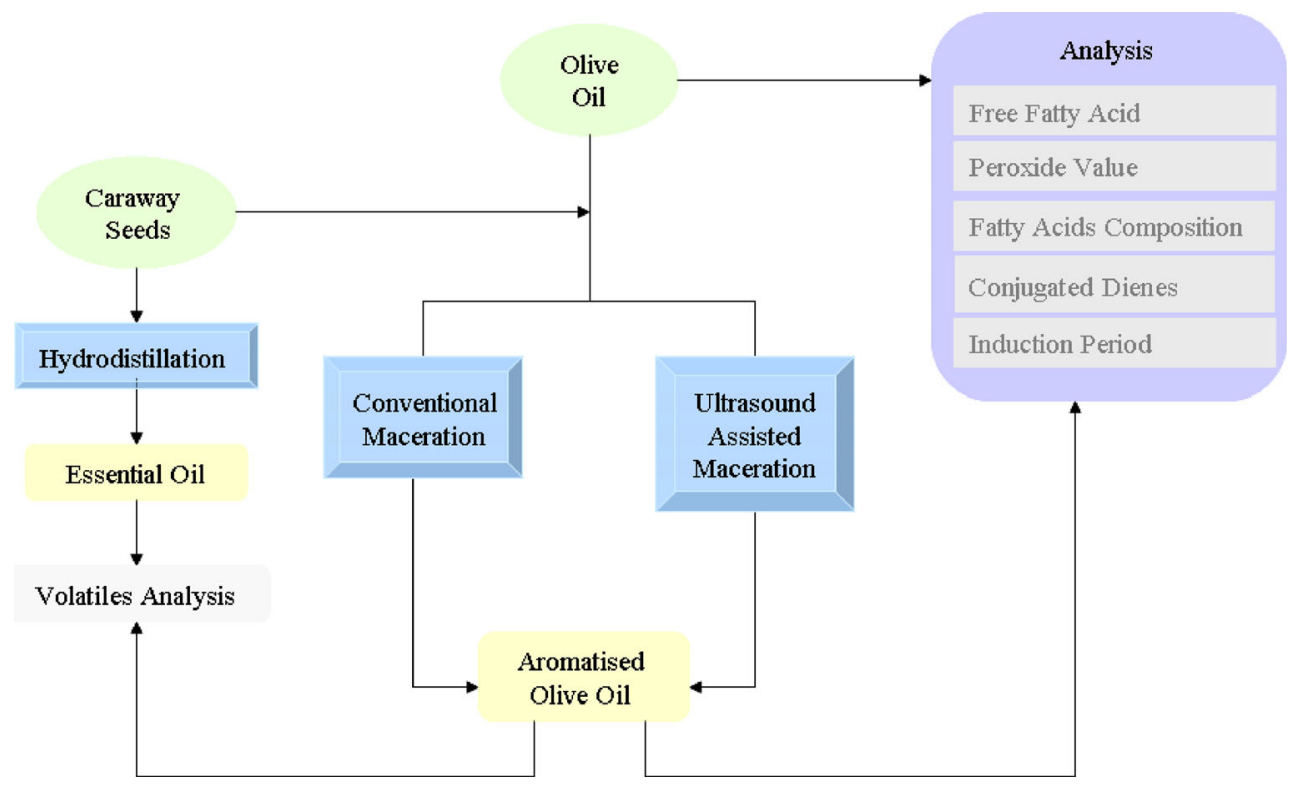

samplings for aromatisation kinetics purposes. Our preliminary assays indicated that beyond $6 \mathrm{~h}(720 \mathrm{~min})$, very little mass transfer is observed, which led us to establish that $6 \mathrm{~h}$ was the optimal infusion time. The final aromatised mixture was filtered through a coffee filter in order to remove traces of crushed seeds, and samples were kept at ambient temperature until further analysis. All experiments were repeated in triplicates, and mean values are reported.

\section{Ultrasound-Assisted Aromatisation}

An ultrasonic system (REUS, France) operating at a frequency of $25 \mathrm{kHz}$ is used (Fig. 2). The ultrasonic reactor consists of a double-mantle stainless steel jug into which cooling water

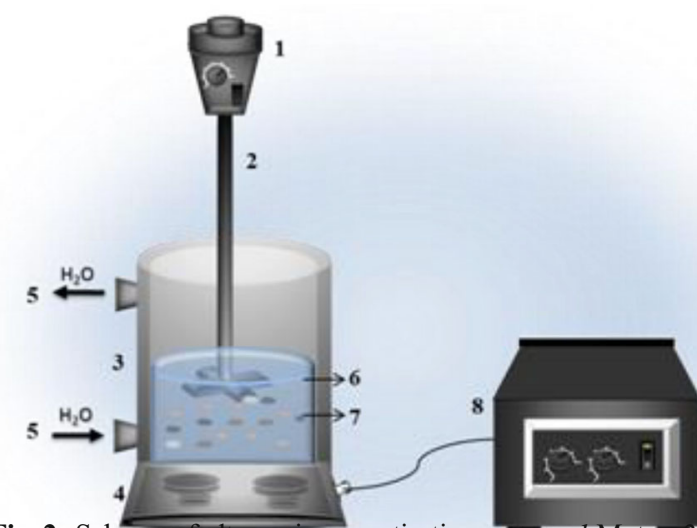

Fig. 2 Scheme of ultrasonic aromatisation sysum. 1 Motor, 2 agitator, 3

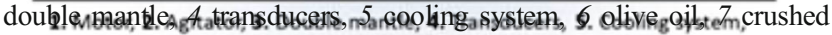
carawayseeds, ol, ult teasøunidgeweratonds, 8. Ultrasound generator. circulates to keep the mixture at constant temperature of $25^{\circ} \mathrm{C}$. Similarly, $150 \mathrm{~g}$ of crushed caraway seeds was placed into the reactor together with $1 \mathrm{~L}$ of olive oil and the mixture was homogenised during ultrasound processing using a rotating pale at a speed of $1000 \mathrm{rpm}$.

In an attempt to determine the real power output converted into ultrasound, power at different points is recorded to estimate ultrasound system efficiency. In this case, consumed power $\mathrm{Cp}$ at the socket (measured using a Watt meter), generated power Gp (using equipment conversion tables) and dissipated power into heat Dp (measuring temperature change of the medium by means of a thermocouple and applying first law of thermodynamics' equation) are registered. The results indicate that increasing generated power Gp (i.e. consumed power as well) engenders relatively a notable increase in temperature of the medium, attributed to the multiplication of interactions and friction forces as a response to high olive oil viscosity and resistance of ultrasound penetration.

At a fixed power, generator efficiency is evaluated to reach $77 \%$ while converter efficiency is estimated to be $51.6 \%$. Therefore, the global ultrasound system efficiency may reach a maximum of $39.3 \%$. In this situation, temperature increased during time at a linear pattern for which dissipated power Dp is estimated at $1.36 \mathrm{~W} / \mathrm{mL}$ of olive oil.

Furthermore, groundwork trials using ultrasound indicated that saturation is achieved between 20 and $30 \mathrm{~min}$. Therefore, an aromatisation period of $30 \mathrm{~min}$ is selected. The collected mixture was filtered through a coffee filter in order to remove traces of crushed seeds, and samples were kept at ambient temperature until further analysis. Experiments were performed in triplicates, and mean values are reported. 
Version définitive du manuscrit publiée dans / Final version of the manuscript published in :

Food Analytical Methods (2016), Vol. 9, issue 4, p. 982-990, DOI: 10.1007/s12161-015-0273-9

Journal homepage : www.springer.com/journal/12161

\section{Analytical Procedures}

For the analytical procedures, a comparison was performed between three samples, namely olive oil before aromatisation $(\mathrm{OO})$, conventional aromatised olive oil (CAOO) and ultrasound aromatised olive oil (UAOO).

\section{Physico-Chemical Parameters}

In this part, a physico-chemical assessment of oil, before and after aromatisation, is conducted to see changes on free fatty acid (FFA) yield, peroxide value (PV) and absorption coefficients in UV (at 232 and $270 \mathrm{~nm}$ ). These analyses were conducted following analytical protocols described in the European Regulations (EUC 2013). Experiments were performed in triplicates, and mean values are reported with standard deviation.

\section{Fatty Acid Composition}

Before injection, olive oil samples are dissolved first in $n$ heptane $(0.12 \mathrm{~g} / 2 \mathrm{~mL})$ and then trans-methylated with a cold solution of $\mathrm{KOH}(2 \mathrm{M})(1 \mathrm{~mL})$ (Galtier et al. 2007). The resulting fatty acid methyl esters (FAMEs) were analysed on an Agilent 6890 GC coupled to a 5973A MS using fused silica capillary column with polar phase, Stabilwax, consisting of Carbowax ${ }^{\mathrm{TM}}$ PEG $(60 \mathrm{~m} \times 0.25 \mathrm{~mm}$ internal diameter (i.d. $) \times$ $0.25-\mu \mathrm{m}$ film thickness). The oven temperature program is performed as follows: $13 \mathrm{~min}$ at $200^{\circ} \mathrm{C}$, then increasing from 200 to $230^{\circ} \mathrm{C}$ at $6{ }^{\circ} \mathrm{C} / \mathrm{min}$, and finally held $17 \mathrm{~min}$ at $230^{\circ} \mathrm{C}$. The injection port and ionising source were kept at 250 and $230{ }^{\circ} \mathrm{C}$, respectively. One-microliter samples are injected using a split ratio of 70:1. Helium is used as carrier gas with a flow of $0.7 \mathrm{~mL} / \mathrm{min}$ using an electronic impact ionisation mode at ionisation energy of $70 \mathrm{eV}$.

\section{Volatile Analysis}

Essential oil's components that are believed to have infused in olive oil are detected using a headspace solid-phase microextraction gas chromatograph coupled to mass spectrometer (HS-SPME-GC/MS) as described earlier by Veillet et al. (2010). In this situation, $4 \pm 0.032 \mathrm{~g}$ of olive oil is inserted in a 20 - $\mathrm{mL}$ vial preincubated at $40^{\circ} \mathrm{C}$ for $15 \mathrm{~min}$. The volatile compounds contained into the vial's headspace are left for $30 \mathrm{~min}$ to be absorbed on a SPME fibber $(75-\mu \mathrm{m}$ carboxenpolydimethylsiloxane) under magnetic stirring of the oil.

The resulting volatiles are automatically injected into Agilent 6890 GC coupled to a 5973A MS detector using fused silica capillary column with polar phase, Stabilwax, consisting of Carbowax ${ }^{\text {TM }}$ PEG $(60 \mathrm{~m} \times 0.25 \mathrm{~mm}$ i.d. $\times 0.25-\mu \mathrm{m}$ film thickness). The initial oven temperature is held at $45^{\circ} \mathrm{C}$ for $3 \mathrm{~min}$. Then, it is increased by $3{ }^{\circ} \mathrm{C} / \mathrm{min}$ to $250^{\circ} \mathrm{C}$ and held for
$5 \mathrm{~min}$ at this temperature. The injector temperature is set at $250{ }^{\circ} \mathrm{C}$, and desorption time of the fibber into the injection port is fixed at $5 \mathrm{~min}$ in a splitless mode. Helium is used as carrier gas with a flow of $0.7 \mathrm{~mL} / \mathrm{min}$. The ionising source is kept at $230{ }^{\circ} \mathrm{C}$, and the ionisation mode used is electronic impact (EI) at ionisation energy of $70 \mathrm{eV}$. Component identification is confirmed by comparison of mass spectral fragmentation patterns with those stored in the MS data bank (Wiley 7) and compared with published data (Ferhat et al. 2010; Assami et al. 2012).

\section{Accelerated Oxidation Tests}

Measurement of the induction period (IP) is performed using the well-established Rancimat method using Rancimat model 734 (Metrohm, Herisau, Switzerland) operating at $120{ }^{\circ} \mathrm{C}$ (Tura et al. 2007). A dry air flow of $20 \mathrm{~L} / \mathrm{h}$ was passed through an oil sample of $3 \pm 0.001 \mathrm{~g}$. The volatile oxidation products, arising from the oxidation test, were dissolved in cold Milli-Q water $(60 \mathrm{~mL})$ causing an increase in the electrical conductivity. The concept is based on conductivity change of the distillate collected from an oil sample that was submitted to an accelerated oxidation at a prefixed temperature. This conductivity change is attributed to the production of formic and other carboxylic acids as a consequence of forced oxidation of secondary products. These experiments were performed in triplicate, and the mean value is reported (Table 1). In this case, the time taken to reach an inflection point at the induction curve is considered for oil stability index (OSI) calculations.

\section{Statistical Analysis}

One-way analysis of variance (ANOVA) was used using Statgraphics $\mathrm{V}^{\circledR}$ software (Statistical Graphics Corp., Rockville, MD). Each measurement was replicated three times, and a Tukey multiple range test method was used to point out deviation from the mean value. In this case, trends were considered significant only where means of compared parameters are different at $P<0.05$ significance level.

\section{Scanning Electron Micrographs}

In an attempt to explain extraction mechanism, after each extraction, seeds' residues are sampled for scanning electron micrographs. The specimens were plunged in liquid nitrogen and then cut with a cold knife. The sectioned particles were fix on a specimen holder with aluminium tape and then sputtered with gold in sputter coater. All the specimens were examined using FEI-Philips XL30 scanning electron microscope under standard vacuum conditions. 
Version définitive du manuscrit publiée dans / Final version of the manuscript published in :

Food Analytical Methods (2016), Vol. 9, issue 4, p. 982-990, DOI: 10.1007/s12161-015-0273-9

Journal homepage : www.springer.com/journal/12161

Table 1 Physicochemical parameters and fatty acid composition of studied olive oil

\begin{tabular}{llll}
\hline Parameters & OO & CAOO & UAOO \\
\hline FFA (\% of oleic acid) & $0.46 \pm 0.02$ & $0.48 \pm 0.03$ & $0.53 \pm 0.02^{*}$ \\
$\mathrm{PV} \mathrm{(meq} \mathrm{O}_{2} \mathrm{~kg}^{-1}$ ) & $2.1 \pm 0.4$ & $2.7 \pm 0.2$ & $2.4 \pm 0.4$ \\
$\mathrm{~K} 232$ & $1.69 \pm 0.05$ & $1.76 \pm 0.01$ & $1.99 \pm 0.05$ \\
$\mathrm{~K} 270$ & $0.14 \pm 0.02$ & $0.16 \pm 0.02$ & $0.19 \pm 0.03$ \\
Induction period (IP) (h) & $3.45 \pm 0.5$ & $4.53 \pm 0.5$ & $6.39 \pm 1 *$ \\
Fatty acid composition (\%) & & & \\
$\quad$ Palmitic acid & $17.78 \pm 0.58$ & $18.39 \pm 0.57$ & $18.14 \pm 0.57$ \\
$\quad$ Palmitoleic acid & $0.10 \pm 0.02$ & $0.10 \pm 0.03$ & $0.10 \pm 0.02$ \\
$\quad$ Margaric acid & $1.77 \pm 0.04$ & $1.89 \pm 0.04$ & $1.68 \pm 0.03$ \\
$\quad$ Stearic acid & $1.57 \pm 0.04$ & $1.59 \pm 0.06$ & $1.57 \pm 0.01$ \\
$\quad$ Oleic acid & $63.96 \pm 1.33$ & $62.47 \pm 1.08$ & $62.36 \pm 0.87$ \\
Linoleic acid & $10.26 \pm 0.16$ & $10.24 \pm 0.13$ & $9.79 \pm 0.13$ \\
Linolenic acid & $0.55 \pm 0.03$ & $0.53 \pm 0.01$ & $0.51 \pm 0.01$ \\
$\quad$ Arachidic acid & $0.28 \pm 0.06$ & $0.36 \pm 0.02$ & $0.35 \pm 0.05$ \\
$\quad$ Saturated fatty acids (SFA) & $25.13 \pm 0.26$ & $26.66 \pm 0.26$ & $27.24 \pm 0.27$ \\
Monounsaturated fatty acids & $64.06 \pm 0.92$ & $62.57 \pm 0.74$ & $62.46 \pm 0.60$ \\
$\quad$ MUFA) & & & \\
Polyunsaturated fatty acids & $10.81 \pm 0.09$ & $10.77 \pm 0.08$ & $10.30 \pm 0.08$ \\
$\quad$ PUFA) & 6.23 & 6.10 & 6.36 \\
Oleic/linoleic ratio & & & \\
\hline & & & \\
\hline
\end{tabular}

$P$ value was determined by one-way analysis of variance (ANOVA) with Tukey multiple range test method

$O O$ olive oil, $C A O O$ conventional aromatized olive oil, UAOO ultrasound aromatized olive oil

$* P<0.05$ significance level

\section{Results and Discussion}

\section{Physico-Chemical Analysis}

For the three samples, olive oil before aromatisation (OO), conventional aromatised olive oil (CAOO) and ultrasound aromatised olive oil (UAOO), the free fatty acid (FFA) values reported on Table 1 remained below the limit $(0.8 \mathrm{~g}$ of oleic acid per $100 \mathrm{~g}$ ) required for virgin olive oil by the IOOC (IOOC International Olive Oil Council 2015). In this situation, FFA values ranged from $0.46 \%$ for non-aromatised oil (OO) to $0.53 \%$ for the oil aromatised by ultrasound (UAOO). In addition, the results indicate an increase on peroxide value (PV) of oils aromatised conventionally (CAOO) with 2.7 meq $\mathrm{O}_{2} \mathrm{~kg}^{-1}$ in comparison to un-aromatised oil; however, this increase is far lower than the upper limit of 20 meq $\mathrm{O}_{2}$ $\mathrm{kg}^{-1}$, permitted by the IOOC. These results suggest that processing did not alter oils that underwent aromatisation.

In another part, the absorbance measurements indicate a slight increase for ultrasound-treated samples in K232 (conjugated dienes) and K270 (conjugated trienes) compared to conventional maceration. Nevertheless, this increase attributed eventually to the production of conjugated dienes and other secondary oxidation compounds is not alarming and remains within the EC permitted values of 2.5 for K232 and 0.25 for K270 (EUC 2013).

We hypothesise that this increase is mainly attributed to rapid temperature increase as a consequence of high frictions forces as a response to high olive oil viscosity during ultrasound treatment as evidenced by ultrasound equipment efficiency findings reported above.

Despite a statistically significant increase in FFA and K232 data observed for UAOO relative to CAOO and $\mathrm{OO}(p<0.05)$, still, these values remain below the IOOC limits (2015). This

Table 2 Caraway essential oil composition analysed by GC/MS

\begin{tabular}{|c|c|c|c|c|}
\hline No. & Compound $^{\mathrm{a}}$ & R.I. ${ }^{\mathrm{b}}$ & R.I. $^{\mathrm{c}}$ & $\mathrm{HD}(\%)$ \\
\hline & Monoterpenes & & & 46.00 \\
\hline 1 & Pinene $<$ alpha- $>$ & 929 & 1024 & 0.04 \\
\hline 2 & Sabinene & 968 & 1122 & 0.03 \\
\hline 3 & Myrcene $<$ beta- $>$ & 989 & 1163 & 0.35 \\
\hline 4 & Limonene & 1031 & 1212 & 45.49 \\
\hline 5 & Ocimene $<$ beta- $>$ & 1046 & 1250 & 0.01 \\
\hline \multirow[t]{2}{*}{6} & Terpinene <gamma-> & 1054 & 1246 & 0.09 \\
\hline & Oxygenated monoterpenes & & & 53.43 \\
\hline 7 & Linalool & 1086 & 1535 & 0.02 \\
\hline 8 & Limonene oxide $<$ cis- $>$ & 1127 & 1445 & 0.01 \\
\hline 9 & Limonene oxide $<$ trans- $>$ & 1132 & 1458 & 0.15 \\
\hline 10 & Dihydrocarvone $<$ cis- $>$ & 1188 & 1620 & 0.01 \\
\hline 11 & Isoanethole & 1190 & 1627 & 0.02 \\
\hline 12 & Dihydrocarvone $<$ trans- $>$ & 1195 & 1639 & 0.01 \\
\hline 13 & Carveol & 1226 & 1869 & 0.14 \\
\hline 14 & Carvone & 1218 & 1763 & 52.86 \\
\hline 15 & Perillal & 1267 & 1804 & 0.15 \\
\hline \multirow[t]{2}{*}{16} & Anethole & 1273 & 1842 & 0.06 \\
\hline & Sesquiterpenes & & & 0.08 \\
\hline 17 & Elemene $<$ beta- $>$ & 1383 & 1599 & 0.02 \\
\hline 18 & Caryophyllene $<$ trans- $>$ & 1409 & 1611 & 0.04 \\
\hline \multirow[t]{2}{*}{19} & Germacrene $<\mathrm{d}->$ & 1471 & 1734 & 0.01 \\
\hline & Oxygenated sesquiterpenes & & & 0.01 \\
\hline \multirow[t]{2}{*}{20} & Caryophyllene oxide & 1575 & 2006 & 0.01 \\
\hline & Other oxygenated compounds & & & 0.01 \\
\hline 21 & Dihydrocarveol acetate & 1318 & 1810 & 0.01 \\
\hline \multicolumn{4}{|c|}{ Extraction time (min.) } & 180 \\
\hline \multicolumn{4}{|c|}{ Yield (\%) } & 1.86 \\
\hline \multicolumn{4}{|c|}{ Total oxygenated compounds (\%) } & 53.45 \\
\hline \multicolumn{4}{|c|}{ Total non-oxygenated compounds (\%) } & 46.08 \\
\hline
\end{tabular}

${ }^{\text {a }}$ Essential oil compounds sorted by chemical families and percentages calculated by GC-MS on non-polar HP5MS ${ }^{\mathrm{TM}}$ capillary column

${ }^{\mathrm{b}}$ Retention index relative to $\mathrm{C}_{5}-\mathrm{C}_{28} n$-alkanes, calculated on non-polar $\mathrm{HP} \mathrm{MS}^{\mathrm{TM}}$ capillary column

${ }^{\mathrm{c}}$ Retention index relative to $\mathrm{C}_{5}-\mathrm{C}_{28} n$-alkanes, calculated on polar Stabilwax ${ }^{\mathrm{TM}}$ PEG capillary column 
Fig. 3 Kinetics of Carvone recovery using ultrasoundassisted maceration (closed circles) versus to conventional maceration (open circles)

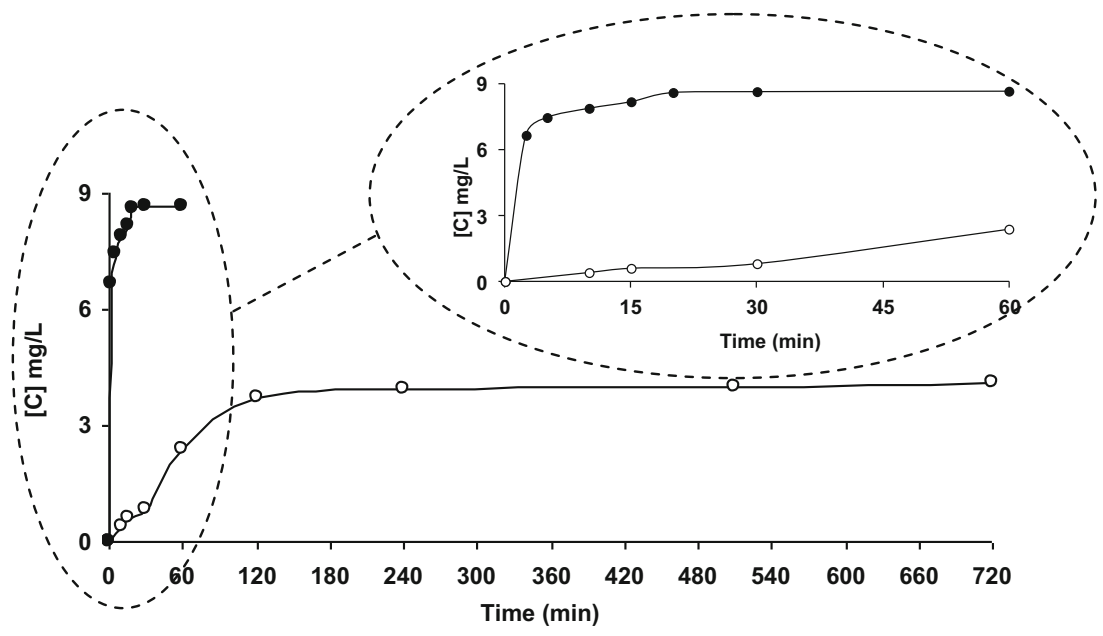

finding is another evidence in favour of ultrasound-assisted aromatisation; it is clear that ultrasound did not affect olive oil quality.

\section{Accelerated Oxidation Tests}

The results reported on Table 1 show that the induction period (IP) varies according to each olive oil sample. UAOO samples represent the highest IP value with $6.39 \mathrm{~h}$ followed by CAOO (4.45 h) and, finally, the untreated sample OO (3.45 h). Statistically speaking, the IP values for UAOO samples were significantly $(p<0.05)$ higher than CAOO and OO. Generally, oxidative stabilities of oils are attributed to the combination of fatty acid composition and the effect of various proantioxidants present in the olive oil (Hrncirik and Fritsche 2005). It is important to highlight that caraway essential oil presents valuable antioxidant activities (Samojlik et al. 2010), which may explain, in part, noticeable increases in IP of aromatised olive oil, particularly for UAOO, since essential oil yield using ultrasound is more important compared to CAOO sample. These results suggest that ultrasound-

Fig. 4 Kinetics of limonene recovery using ultrasoundassisted maceration (closed circles) versus to conventional maceration (open circles) assisted treatment grants an added value for samples by increasing their IPs, i.e. shelf life time, so treatment by means of ultrasound contributes to a longer preservation period of packaged foods.

\section{Fatty Acid Composition}

The composition of fatty acids is reported on Table 1. The major fatty acids present in raw olive oil are as follows: oleic acid (C18:1) $64 \%$, palmitic acid (C16:0) $17.8 \%$, linoleic acid (C18:2) 10.3\% and stearic acid (C18:0) with 1.6\%.

As shown in Table 1, total monounsaturated fatty acids (MUFA) include the largest fatty acid group in the studied olive oil ranging, respectively, for UAOO and OO samples (62.46-64.06 \%), followed by saturated fatty acids (27.24$25.13 \%)$ and then polyunsaturated fatty acids (10.30$10.81 \%$ ). In this context, slight difference in fatty acid composition is observed, indicating that aromatisation procedure did not affect fatty acid composition. In addition, MUFA value remains intact which indicates that no oxidation was happening during processing. In another part, calculations of oleic/

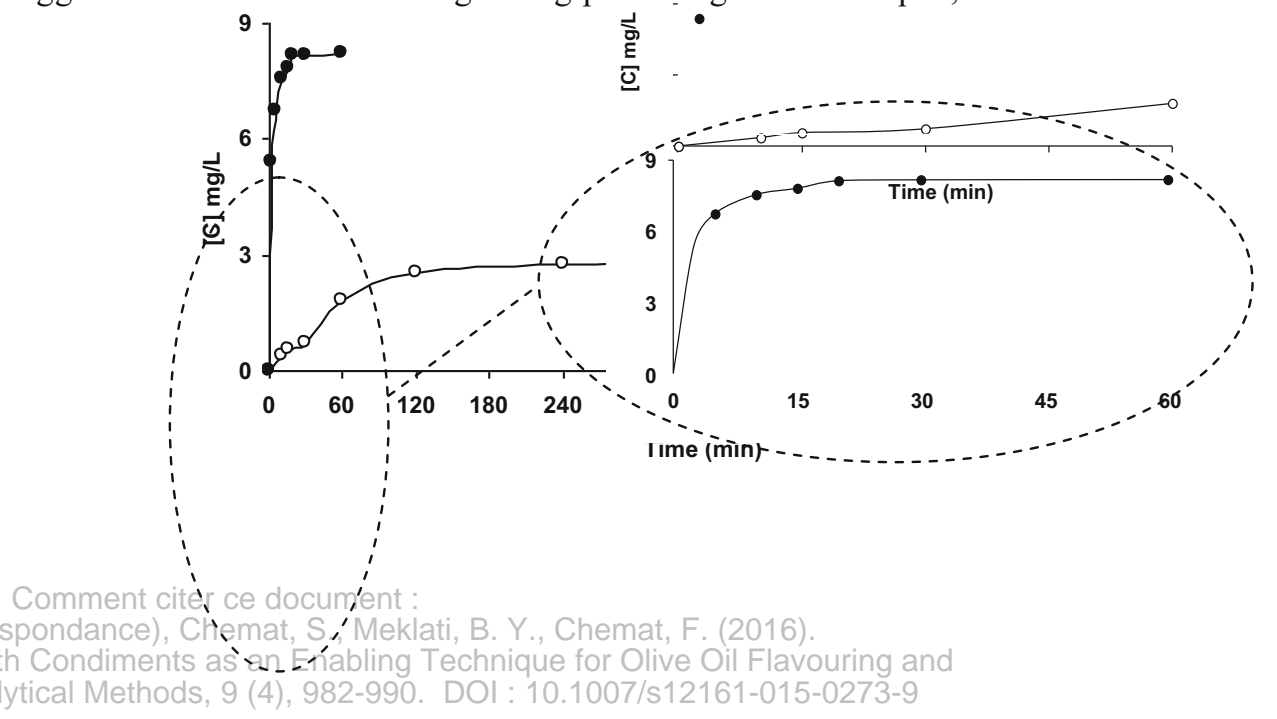


Version définitive du manuscrit publiée dans / Final version of the manuscript published in :

Food Analytical Methods (2016), Vol. 9, issue 4, p. 982-990, DOI: 10.1007/s12161-015-0273-9

Journal homepage : www.springer.com/journal/12161

linoleic acid ratios $(\mathrm{O} / \mathrm{L})$ for non-treated, conventional and ultrasonic treated olive oils give, respectively, 6.23, 6.10 and 6.36 which correlate well with an olive oil characterised as stable portraying a long shelf life as reported by Aparicio et al. (1999) and Rotondi et al. (2004).

\section{Essential Oil Composition}

For aromatisation purposes, caraway seeds were extracted using hydrodistillation giving a yield of $1.86 \%(w / w)$. According to our previous studies (Assami et al. 2012), 21 volatile secondary metabolites were identified and grouped into five classes. In this study, oxygenated monoterpenes represent around $54 \%$ of total oil versus $46 \%$ of non-oxygenated compounds (Table 2). The major compounds were identified as carvone $52.86 \%$ and limonene $45.49 \%$ of essential oil.

\section{Comparison of Aromatisation Methods}

According to the previous section, carvone and limonene represent the major compounds; therefore, these two compounds were selected as indicators of the aromatisation level of olive oil samples. First of all, calibration curves for both compounds were established in order to estimate their concentrations in aromatised olive oils. In this case, different concentrations of carvone and limonene standards were prepared in olive oil and analysed by HS-SPME-GC/MS.

Moreover, samples of olive oils were taken at different periods of maceration in order to capture the efficiency of the aromatisation process. In Figs. 3 and 4, a significant difference between ultrasound-assisted and conventional maceration is observed during all the processing period. For ultrasound, it appears that only $10 \mathrm{~min}$ is required to reach equilibrium of $90 \%$ essential oil recovery then reaching its maximum value at $30 \mathrm{~min}$ with 8.75 and $8.27 \mathrm{mg} / \mathrm{L}$ for carvone and limonene, respectively. In parallel, conventional procedure failed to meet the same rate recovering only $0.81 \mathrm{mg} / \mathrm{L}$ for carvone and $0.73 \mathrm{mg} / \mathrm{L}$ for limonene. Even after $12 \mathrm{~h}$ of conventional processing, still, only 4.21 and $2.81 \mathrm{mg} / \mathrm{L}$, respectively, for carvone and limonene could be achieved. These values remain very low compared to those found under ultrasonic treatment. These results are in accordance with the work of Veillet et al. (2010) on ultrasound-assisted aromatisation of olive oil with basil where they reported that maximum linalool and eugenol yields could be reached in only $30 \mathrm{~min}$ under ultrasound and are two times higher than those obtained at conventional maceration for $72 \mathrm{~h}$.

This fact is attributed to the positive effect of ultrasound on mass transfer intensification through rapid exudation of essential oil components from seeds into the bulk medium, well reported in earlier studies by Vinatoruet ale (1997) and Assampe etali. (2012)teur de correspondance), Chemat, S., Meklati, B. Y., Chemat, F. (2016) 
observation of exploded glands, arguing that essential oil glands located at the surface of the leaves are directly exposed to the intense mechanical stress induced by cavitation bubbles. For conventional processing seeds' residue (Fig. 5c), cell walls appeared intact, but certain dryness in some cells is noticeable, apparently a synonym of exudation at low pace for part of seed content into the bulk medium. Since kinetic studies ascertained a fast liberation of gland content under ultrasound treatment, this micrograph may explain why ultrasound-assisted extraction is faster than the conventional one (Figs. 3 and 4). In this respect, severe localised thermal stresses at the surface of cell walls, allegedly generated by cavitation phenomena, are suggested to be responsible for such damage. This finding corroborates with earlier results which confirms the strong mechanical effect of ultrasound (Chemat and Esveld 2013).

\section{Conclusion}

The findings supported the potential borne by ultrasound treatment in the aromatisation of vegetable oils with condiments in an attempt to enhance quality and shelf life of olive oil.

The application of HS-SPME-GC/MS for the analysis of aromatised virgin olive oil by crushed caraway seeds allowed the detection of significant differences in carvone and limonene proportions in which a faster flavouring rate is registered for ultrasound-assisted system versus the conventional one. Samples treated under ultrasound produced very stable aromatised oil with no changes in quality as revealed by olive oil purity, FFA composition and degree of oxidation analysis. In this part, ultrasound-flavouring process was able, in few minutes, to achieve high yields versus several hours for conventional method. This fact is attributed to ultrasound contribution to mass transfer intensification of essential oil components from seeds to the bulk medium, confirmed by SEM micrographs in which cell damage and exudation of its main content are illustrated.

The results indicate also that IP of olive oil has increased following aromatisation, particularly for ultrasound-treated samples, which is an indication of better quality and extended shelf life granting, therefore, an added value label for ultrasound samples.

\section{Compliance with Ethics Requirements}

Ethical Approval This article does not contain any studies with human or animal subjects by any of the authors.

Conflict of Interest Karim Assami declares that he has no conflict of interest. Smain Chemat declares that he has no conflict of interest. Brahim Y. Meklati declares that he has no conflict of interest. Farid Chemat declares that he has no conflict of interest.

\section{References}

Angerosa F, Servili M, Selvaggini R, Taticchi A, Esposto S, Montedoro G (2004) Volatile compounds in virgin olive oil: occurrence and their relationship with the quality. J Chromatogr A 1054:17-31

Aparicio R, Roda L, Albi MA, Gutierez F (1999) Effect of various compounds on virgin olive oil stability measured by Rancimat. J Agr Food Chem 47:4150-4155

Assami K, Pingret D, Chemat S, Meklati BY, Chemat F (2012) Ultrasound induced intensification and selective extraction of essential oil from (Carum carvi L.) seeds. Chem Eng Process 62:99-105

Chemat S, Esveld EDC (2013) Contribution of microwaves or ultrasonics on carvone and limonene recovery from dill fruits (Anethum graveolens L.). Innov Food Sci Emerg 17:114-119

Clevenger JF (1928) Apparatus for volatile oil determination, description of new type. Am Perfumer Essent Oil Rev 17:345-349

Damechki M, Sotiropoulou S, Tsimidou M (2001) Antioxidant and prooxidant factors in oregano and rosemary gourmet olive oils. Grasas Aceites 52:207-213

Elmastas M, Dermirtas I, Isildak O, Aboul-Enein HY (2006) Antioxidant activity of S-carvone isolated from spearmint (Mentha spicata L. fam Lamiaceae). J Liquid Chromatogr R T 29:1465-1475

EUC (2013) European Union Regulation (EU) No 1348/2013 amending Regulation (EEC) No 2568/91 on the characteristics of olive oil and olive-residue oil and on the relevant methods of analysis. Official J Eur Communities L 338:31-67

Ferhat A, Fabiano-Tixier AS, Visinoni F, Romdhane M, Chemat F (2010) A surprising method for green extraction of essential oil from dry spices: microwave dry-diffusion and gravity. J Chromatogr A 1217: $7345-7350$

Galanakis CM (2012) Recovery of high added-value components from food wastes: conventional, emerging technologies and commercialized applications. Trends Food Sci Tech 26:68-87

Galanakis CM (2013) Emerging technologies for the production of nutraceuticals from agricultural by-products: a viewpoint of opportunities and challenges. Food Bioprod Process 91:575-579

Galtier O, Dupuy N, Le Dréau Y, Ollivier D, Pinatel C, Kister J, Artaud J (2007) Geographic origins and compositions of virgin olive oils determinated by chemometric analysis of NIR spectra. Anal Chim Acta 595:136-144

Gambacorta G, Faccia M, Pati S, Lamacchia C, Baiano A, La Notte E (2007) Changes in the chemical and sensorial profile of extra virgin olive oils flavored with herbs and spices during storage. J Food Lipid 14:202-215

Hrncirik K, Fritsche S (2005) Relation between the endogenous antioxidant system and the quality of extra virgin olive oil under accelerated storage conditions. J Agr Food Chem 53:2103-2110

International Olive Oil Council (IOOC) (2009). Olive growing in Algeria. E.108/Doc. no. 4, 02: 2. URL http://www.internationaloliveoil.org/ estaticos/view/136-country-profiles. Accessed 30 May 2014.

International Olive Oil Council (IOOC) (2015). Trade standard applying to olive oil and olive-pomace oil. COI/T15/NC No 3, Rev. 8 February

ISO (1987). Huile essentielle de carvi (Carum carvi Linnaeus). ISO 8896: 1987.

Jimnez de Bias O, del Valle Gonzalez A (1996) Determination of sterols by capillary column gas chromatography. Differentiation among different types of olive oil: virgin, refined, and solvent-extracted. J Am Oil Chem Soc 73:1685-1689

Luaces P, Perez AG, Sanz C (2003) Role of olive seed in the biogenesis of virgin olive oil aroma. J Agr Food Chem 51:4741-4745

Luque-Garcia JL, Luque de Castro MD (2004) Ultrasound-assisted Soxhlet extraction: an expeditive approach for solid sample treatment: application to the extraction of total fat from oleaginous seeds. J Chromatogr A 1034:237-242 
Moldão-Martins M, Beirão-da-Costa S, Neves C, Cavaleiro C, Salgueiro L, Beirão-da-Costa ML (2004) Olive oil flavoured by the essential oils of Mentha x piperita and Thymus mastichina L. Food Qual Prefer 15:447-452

Morales MT, Aparicio R, Rios JJ (1994) Dynamic headspace gas chromatographic method for determining volatiles in virgin olive oil. $\mathrm{J}$ Chromatogr A 668:455-462

Ollivier D, Artaud J, Pinatel C, Durbec JP, Guerere M (2003) Triacylglycerol and fatty acid composition of French virgin olive oils. Characterization by chemometrics. J Agr Food Chem 51: 5723-5731

Roberto D, Micucci P, Sebastian T, Graciela F, Anesini C (2010) Antioxidant activity of limonene on normal murine lymphocytes: relation to $\mathrm{H} 2 \mathrm{O} 2$ modulation and cell proliferation. Basic Clin Pharmacol 106:38-44

Rotondi A, Bendini A, Cerretani L, Mari M, Lercker G, Gallina Toschi T (2004) Effect of olive ripening degree on the oxidative stability and organoleptic properties of cv Nostrana di Brisighella extra virgin olive oil. J Agr Food Chem 52:3649-3654

Samojlik I, Lakic N, Mimica-Dukic N, Dakovic-Svajcer K, Bozin B (2010) Antioxidant and hepatoprotective potential of essential oils of coriander (Coriandrum sativum L.) and caraway (Carum carvi L.) (Apiaceae). J Agr Food Chem 58:8848-8853
Tripoli E, Giammanco M, Tabacchi G, Di Majo D, Giammanco S, La Guardia M (2005) The phenolic compounds of olive oil: structure, biological activity and beneficial effects on human health. Nutr Res Rev 18:98-112

Tura D, Gigliotti C, Pedo S, Failla O, Bassi D, Serraiocco A (2007) Influence of cultivar and site of cultivation on levels of lipophilic and hydrophilic antioxidants in virgin olive oils (Olea europea L.) and correlations with oxidative stability. Sci Hortic Amesterdam 112:108-119

Van Boom SS, Van der Brugghen R, Reinout Maitland R (2002) Method for flavoring an olive oil, US PAT. 0,164, $413 \mathrm{~A} 1$

Veillet S, Tomao V, Chemat F (2010) Ultrasound assisted maceration: an original procedure for direct aromatisation of olive oil with basil. Food Chem 123:905-911

Vinatoru M, Toma M, Radu O, Filip PI, Lazurca D, Mason TJ (1997) The use of ultrasound for the extraction of bioactive principles from plant materials. Ulrason Sonochem 4:135-139

Visioli F, Galli C (2002) Biological properties of olive oil phytochemicals. Cr Rev Food Sci Nutr 42:209-221

Wei F, Gao GZ, Wang XF, Dong XY, Li PP, Hua W, Wang X, Wu XM, Chen H (2008) Quantitative determination of oil content in small quantity of oilseed rape by ultrasound-assisted extraction combined with gas chromatography. Ulrason Sonochem 15:938-942 